\title{
PENGARUH PENAMBAHAN VARIASI GEOMETRI STERN FLAP TERHADAP NILAI HAMBATAN PADA KAPAL PATROLI PERIKANAN
}

\author{
Rosiana Dewi ${ }^{1}$, Untung Budiarto ${ }^{2}$, Ari Wibawa Budi Santosa ${ }^{3}$, Eko Sasmito Hadi ${ }^{4}$, Parlindungan Manik ${ }^{5}$, Ocid \\ Mursid $^{6}$ \\ Departemen Teknik Perkapalan \\ Universitas Diponegoro \\ rsndewi1999@gmail.com¹, untungb@undip.ac.id², arikapal75@gmail.com³ , ekosasmitohadi@gmail.com4, \\ parlin1974@yahoo.com ${ }^{5}$, ocidmursid@gmail.com ${ }^{6}$
}

\begin{abstract}
ABSTRAK
Optimalisasi performa hidrodinamika kapal dengan mereduksi hambatan kapal patroli planing hull berkecepatan tinggi merupakan salah satu upaya pencegahan peningkatan khasus illegal fishing, dan instalasi stern flap merupakan upaya sederhana dalam mereduksi nilai hambatan. Menurut sejarah penelitian terdahulu, dibutuhkan studi lebih lanjut dalam pengeksplorasian ragam geometri stern flap. Pada penelitian ini dilakukan analisis pengaruh variasi geometri stern flap untuk mengetahui nilai hambatan dari kapal patroli perikanan dengan pendekatan numerikal CFD. Komputasi diselesaikan dengan persamaan Reynolds-Averaged Navier Stokes (RANS) serta teknik solusi Finite Volume Method (FVM) pada perairan tenang menggunakan model turbulensi k- $\varepsilon$ dan model fisika fluida eulerian multiphase yaitu Volume of Fluid (VOF) yang terdiri dari fasa air dan fasa udara untuk merepresentasikan free surface. Meshing geometri menggunakan metode overset mesh dengan konsep donor-acceptor cells. Penelitian dilakukan pada 5 kondisi Froude number dan 9 buah model stern flap. Diperoleh pengurangan nilai hambatan total tertinggi yaitu $-26,07 \%$ pada Fr 1,00, sedangkan penambahan nilai hambatan tertinggi yaitu $31,71 \%$ pada Fr 1,33. Terdapat 2 variasi bentuk stern flap yang mampu mereduksi nilai hambatan pada seluruh nilai Froude number.
\end{abstract}

Kata kunci : Planing hull, Stern flap, CFD, Hambatan, Trim, Heave

\begin{abstract}
Optimizing ship hydrodynamics performance through resistance reduction of a high-speed planing hull patrol boat is known as one of the ways to prevent the increase of illegal fishing cases, and stern flap installation was found to be a simple way to reduce resistance. Reflecting on some previous researches, further work on investigating a practical stern flap geometry is needed. Hereby conducted an influence analyze of stern flap geometry variations on resistance performance of a fishing patrol boat with CFD numerical approaches. Reynolds-Averaged Navier Stokes equation was applied to solve the computation with Finite Volume Method technique on calm water using $k-3$ model turbulence and the Volume of Fluid eulerian multiphase physics model that could track the interface between water and air phases to capture the free surface area. Overset mesh method was chosen to generate mesh geometry by donor-acceptor cells concept. This study carried out on five Froude number conditions and nine model of stern flaps. Results obtained that the highest resistance reduction happens about $-26,07 \%$ on $\mathrm{Fr} 1,00$, while the highest resistance increase was about 31,71\% on Fr 1,33. Two stern flap geometry variations successfully reduce the ship's total resistance at all Froude number conditions
\end{abstract}

Keywords : Planing hull, Stern flap, CFD, Total Resistance, Trim, Heave 


\section{Pendahulan}

Berdasarkan pendapat Muhamad (2012), salah satu penyebab meningkatnya jumlah khasus illegal fishing di perairan Indonesia yaitu besarnya dana operasional bahan bakar kapal patroli sehingga kegiatan pengawasan menjadi terbatas (Muhamad, 2012). Penekanan konsumsi bahan bakar kapal erat kaitannya dengan efisiensi daya dorong mesin kapal, hal tersebut dapat dicapai dari mereduksi nilai hambatan total dengan memperbaiki performa hidrodinamika kapal. Kapal patroli umumnya berupa kapal cepat berbentuk planing hull (Maulana, 2018) dimana kapal pada fase planing hampir seluruh beratnya disangga oleh lift force sehingga WSA mengecil serta terjadi perubahan trim (Fretes, 2018).

Upaya sederhana yang dinilai mampu memperbaiki performa hidrodinamika kapal patroli yaitu dengan instalasi appendages seperti stern flap (Song et al., 2019). Kombinasi antara stern flap dengan transom buritan dapat memperbaiki bidang aliran wake dengan berkurangnya ketinggian dan lembah gelombang (Klara et al., 2020), gaya drag dan hambatan gelombang dapat berkurang, hingga meminimalisir hilangnya daya (Sun et al., 2020). Geometri stern flap yaitu berupa perpanjangan pelat pada transom kapal yang diatur dengan sudut tertentu terhadap garis air (Yaakob, Shamsuddin and Koh, 2012).

Berdasarkan sejarah perkembangan instalasi stern flap, dalam penelitian Song et al tahun 2018 didapat bahwa pada tahun 1999 oleh Cusanelli \& Hundley telah dilakukan uji eksperimental full scale penambahan stern flap pada kapal FFG-7 Class yang mampu mengurangi daya hingga $11,7 \%$. Disebutkan pula bahwa berkurangnya hambatan total kapal erat hubungannya dengan distribusi wave-making resistance yang membaik (Song et al., 2018). Meninjau pengaruh ragam variasi bentuk geometri dari stern flap, telah dilakukan uji CFD pada kapal planing hull dengan panjang flap $1 \%$ Loa dan sudut kemiringan flap $0^{\circ}$ hambatan kapal dapat berkurang rata-rata 4,5 $\%$, (Yaakob, Shamsuddin and Koh, 2012). Penelitian CFD kapal planing hull lainnya yaitu oleh Maulana tahun 2018 dengan panjang flap 1 2,5 \% Lpp, span selebar transom kapal, dan sudut flap $0^{\circ}$ dinilai efektif mengurangi hambatan hingga 2,87\% (Maulana, 2018). Selanjutnya, telah terdapat pula pengujian towing tank dan CFD dari pemasangan stern flap oleh Maki et al tahun 2016, bahwa stern flap efektif mengurangi nilai hambatan total jika panjang flap 1 2 \% Lwl, span dibuat selebar mungkin, dan variasi sudut flap mampu menghasilkan perbedaan performa yang signifikan (Maki et al., 2016).

Pada penelitian ini ditetapkan penggunaan metode komputasi numerik Computational Fluid Dynamics (CFD) berdasarkan persamaan Reynolds-Averaged Navier Stokes (RANS) dengan teknik solusi numerik Finite Volume Method (FVM) untuk mengetahui nilai hambatan total serta nilai 2-DOF (Degree of Freedom) kapal yaitu heave (gerak translasional pada sumbu Z) dan pitch/ trim (gerak rotasional pada sumbu Y) di perairan tenang dengan permodelan turbulensi k- $\varepsilon$, model fisika fluida eulerian multiphase yang terdiri dari fasa air serta udara dan dengan pendekatan Volume of Fluid (VOF) untuk merepresentasikan kondisi free surface (Sun et al., 2020). Meshing yang digunakan dalam penelitian ini menggunakan metode overset grid dimana objek geometri didiskritasi menggunakan prinsip donor-acceptor cells yang terdiri dari geometri overset sebagai akseptor dan background sebagai pendonor (Fathuddiin et al., 2020).

Dari peninjauan bentuk variasi stern flap pada penelitian Maki et al tahun 2016 (Maki et al., 2016) serta penarikan kesimpulan dari penelitian terdahulu, adapun tujuan dari penelitian ini yaitu untuk menganalisis pengaruh dari penambahan 9 buah variasi bentuk stern flap pada kapal partroli jenis planing hull terhadap perubahan nilai hambatan total, heave, dan pitchl trim.

\section{Metodologi Penelitian \\ 2.1. Objek Penelitian}

Objek penelitian yang digunakan pada penelitian ini merupakan kapal patroli $14 \mathrm{~m}$ dengan detail ukuran utama kapal pada Tabel 1.

Tabel 1. Ukuran Utama Kapal

\begin{tabular}{ccc}
\hline Parameter & Unit & Nilai \\
\hline Loa & $\mathrm{m}$ & 14,10
\end{tabular}




\subsection{Parameter Penelitian}

\begin{tabular}{ccc} 
Lwl & $\mathrm{m}$ & 12,00 \\
$\mathrm{~B}$ & $\mathrm{~m}$ & 3,20 \\
$\mathrm{H}$ & $\mathrm{m}$ & 1,90 \\
$\mathrm{~T}$ & $\mathrm{~m}$ & 0,75 \\
$\mathrm{Cb}$ & & 0,55 \\
Vdinas & knot & 25 \\
Vmax & knot & 28 \\
\hline \multicolumn{2}{l}{ Sumber: (Widyatmoko et al. 2021) }
\end{tabular}

Parameter yang digunakan dalam penelitian ini terfokus pada 9 variasi bentuk stern flap untuk memperoleh informasi variasi stern flap yang paling efektif terhadap perubahan nilai hambatan total kapal patroli planing hull $14 \mathrm{~m}$.

1. Parameter Tetap

a. Kapal patroli $14 \mathrm{~m}$ berbentuk planing hull

b. Lebar span stern flap yaitu $100 \% \mathrm{~B}_{\mathrm{T}}$ (Lebar Transom)

c. Letak stern flap pada bagian bawah transom

d. Geometri penyusun flap mengikuti karakteristik foil NACA N-24 dipotong pada 30\% chord

e. Kapal melaju pada perairan tenang.

2. Parameter Peubah

a. Panjang flap terdiri dari $1,0 \% \mathrm{Lwl}, 1,5 \% \mathrm{Lwl}$, dan $2,0 \% \mathrm{Lwl}$

b. Sudut kemiringan flap terdiri dari $0^{\circ}$, dan $10^{\circ}$

c. Kapal melaju pada Fr 0,33, 0,66, 1,00, 1,19 (kecepatan dinas), dan 1,33.

\subsection{Pemodelan Kapal Patroli}

Kapal yang digunakan pada penelitian didasari oleh data ukuran utama kapal dari objek penelitian. Data kapal digunakan untuk membentuk linesplan kapal menggunakan software Microsoft Excel yang kemudian dimodelkan menjadi 3D dengan bantuan software pemodelan berbasis komputer sehingga model kapal terbentuk seperti pada Gambar 1.

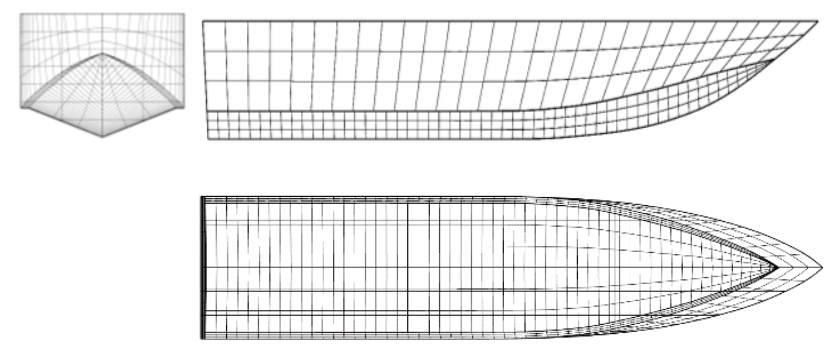

Gambar 1. Pemodelan 3D Kapal Patroli

(Sumber: Hasil pemodelan 3D)

\subsection{Variasi Bentuk Stern flap}

Meninjau pada penelitian dari Maki et al dimana stern flap bukan hanya sebuah perpanjangan plat datar pada bagian bawah transom kapal, namun terdiri dua bagian yaitu bottom area dan upper area (Maki et al., 2016). Maka pada penelitian ini ditetapkan 9 buah variasi bentuk stern flap dengan detail ukuran pada Tabel 2 serta visualisasi model variasi pada Gambar 2 yang kemudian dianalisis dengan bantuan software CFD.

Tabel 2. Variasi bentuk Stern Flap

\begin{tabular}{lccc}
\hline Variasi & \multicolumn{2}{c}{ Bottom area } & Upper area \\
\cline { 2 - 3 } & Center & Side & \\
\hline
\end{tabular}




\begin{tabular}{cccc}
\hline Bare hull & - & - & - \\
Flap 1 & $1,5 \%\left(10^{\circ}\right)$ & $1 \%\left(0^{\circ}\right)$ & $1 \%\left(0^{\circ}\right)$ \\
Flap 2 & $1 \%\left(10^{\circ}\right)$ & $1 \%\left(10^{\circ}\right)$ & $1 \%\left(0^{\circ}\right)$ \\
Flap 3 & $1 \%\left(0^{\circ}\right)$ & $2 \%\left(10^{\circ}\right)$ & $2 \%\left(0^{\circ}\right)$ \\
Flap 4 & $1 \%\left(10^{\circ}\right)$ & $2 \%\left(10^{\circ}\right)$ & $2 \%\left(0^{\circ}\right)$ \\
Flap 5 & $1 \%\left(10^{\circ}\right)$ & $1 \%\left(0^{\circ}\right)$ & - \\
Flap 6 & $1 \%\left(10^{\circ}\right)$ & $1 \%\left(10^{\circ}\right)$ & - \\
Flap 7 & $1 \%\left(10^{\circ}\right)$ & $2 \%\left(10^{\circ}\right)$ & - \\
Flap 8 & $1 \%\left(0^{\circ}\right)$ & $1 \%\left(0^{\circ}\right)$ & - \\
Flap 9 & $1 \%\left(0^{\circ}\right)$ & $1 \%\left(0^{\circ}\right)$ & $1 \%\left(0^{\circ}\right)$ \\
\hline
\end{tabular}

*Nilai persentase menunjukan panjang flap terhadap Lwl kapal. Besar sudut pada bottom area mewakili nilai sudut terhadap keel pada buritan.

Sumber : Maki et al., (2016)

(a)

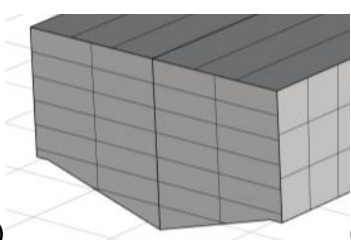

(b)

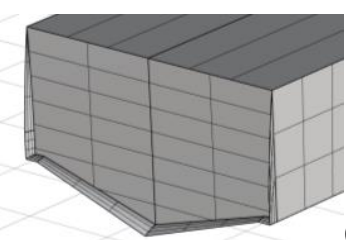

(c)
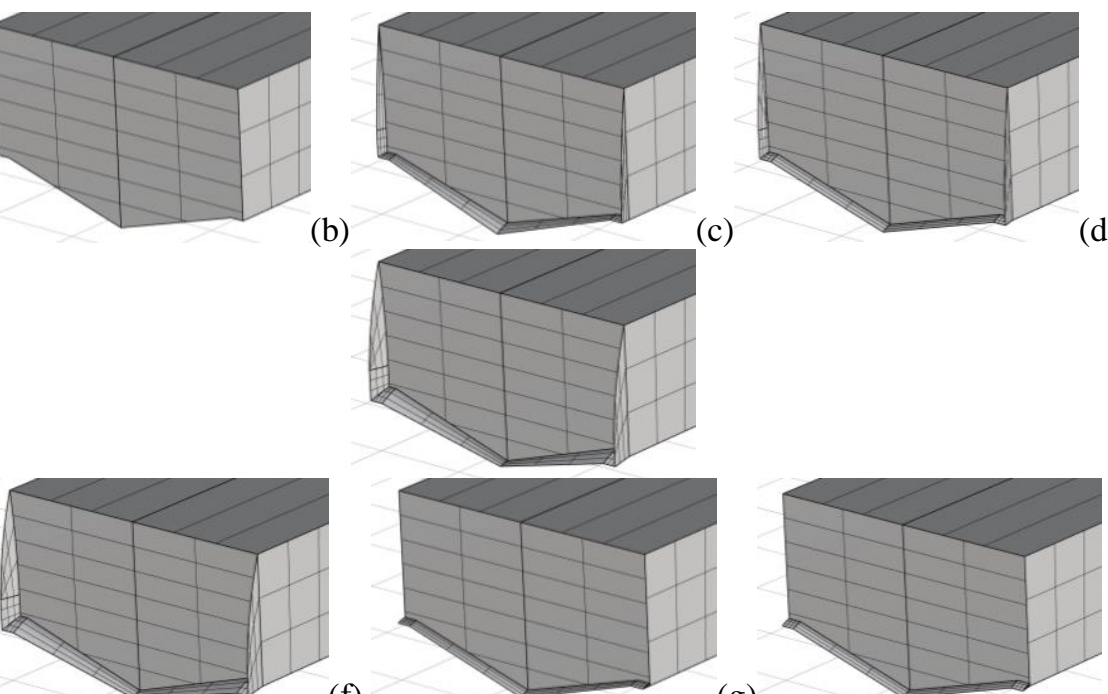

(e) (f)

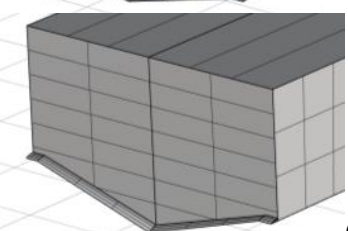

(g)

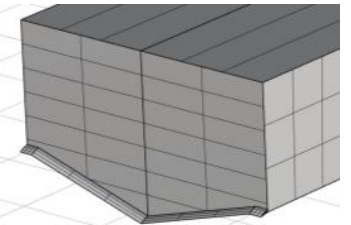

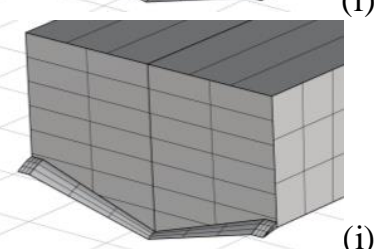

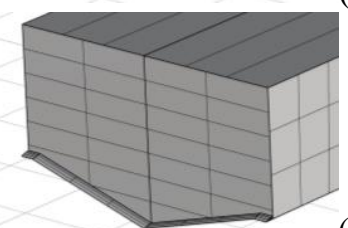

(h)

(i)

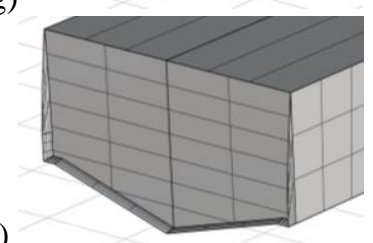

(d)

Gambar 2. (a) Bare hull (b) Flap 1 (c) Flap 2 (d) Flap 3 (e) Flap 4 (f) Flap 5 (g) Flap 6 (h) Flap 7 (i) Flap 8 (j) Flap 9

(Sumber: Hasil Pemodelan 3D)

\subsection{Metode Komputasi Numerik}

Penelitian ini dilaksanakan di Laboratorium Komputer \& Desain Kapal, Departemen Teknik Perkapalan, Universitas Diponegoro. Disamping pengujian eksperimen menggunakan towing tank yang cenderung membutuhkan biaya pengujian cukup besar, dalam perkembangan teknologi dunia maritim telah berkembang dengan pesat cara alternatif untuk memprediksi nilai hambatan kapal menggunakan pendekatan metode komputasi atau CFD (Computational Fluid Dynamics) yang diselesaikan dengan persamaan RANS (Reynolds Averaged Navier Stokes).

RANS dinilai banyak digunakan dalam mensimulasikan karakteristik hidrodinamika kapal. Persamaan RANS digunakan untuk menganalisis performa hambatan setelah dilakukan pemasangan stern flap. Persamaan RANS untuk gerak fluida newtonian-incompressible yaitu (Song et al., 2018): 


$$
\begin{aligned}
& \frac{\partial \rho}{\partial t}+\frac{\partial\left(\rho u_{i}\right)}{\partial x_{i}}=0 \\
& \frac{\partial\left(\rho u_{i}\right)}{\partial t}+\frac{\partial}{\partial x_{j}}\left(\rho u_{i} u_{j}\right)=-\frac{\partial p}{\partial x_{j}}+\frac{\partial}{\partial x_{j}} \mu\left(\frac{\partial u_{i}}{\partial x_{j}}-\rho \overline{u_{\imath}^{\prime}{ }_{l} u_{J}^{\prime}}\right)+S_{j}
\end{aligned}
$$

Dimana $u_{i}$ dan $u_{j}$ adalah nilai rata-rata waktu $(i, j=1,2,3)$ dari komponen kecepatan; $p$ adalah nilai rata-rata waktu dari tekanan; $\rho$ massa jenis fluida; $\mu$ koefisien kecepatan dinamis; $\rho \overline{u^{\prime}{ }_{l} u^{\prime}}$ ialah tegangan Reynolds, dan $S_{\mathrm{j}}$ vektor sumber momentum.

Penyelesaian CFD menggunakan teknik solusi numerik aliran FVM (Finite Volume Methods) yaitu mendiskritkan persamaan diferensial parsial menjadi aljabar pada seluruh domain fluida. FVM mampu memastikan terjaganya kekekalan massa dan momentum dengan proses membagi domain komputasi menjadi finite volume hingga terbentuk mesh/ grid, kemudian PDE dari tiap grid diintegrasi terlebih dahulu sebelum seluruh variabel akhirnya didekatkan dengan nilai grid pusat dan menghasilkan persamaan aljabar (Jokosisworo et al., 2020) (Bertram, 2012).

Untuk mendefinisikan pola gelombang pada free surface digunakan VOF (Volume of Fluid) Method (ITTC, 2011). VOF dikemukakan oleh Hirt dann Nichols pada tahun 1981 dengan asumsi bahwa tiap fasa aliran multi-phase berada dalam kontrol volum yang terpisah dalam hal kecepatan, tekanan, dan fungsi lainnya. Persamaan massa jenis,

$\rho=\sum \rho_{i} \alpha_{i}$

Dan persamaan viskositas kinematik,

$v=\sum v_{i} \alpha_{i}$

Dimana $\alpha_{\mathrm{i}}=\mathrm{V}_{\mathrm{i}} / \mathrm{V}$, nilai $\alpha \mathrm{i}$ (volum fraksi) untuk fasa air yaitu 1 dan untuk fasa udara yaitu 0 , jika nilai $0<\alpha \mathrm{i}<1$ maka merupakan zona fasa campuran (Khazaee, Rahmansetayesh and Hajizadeh, 2019).

Data pada Tabel 3 merupakan domain boundaries atau berupa penyetelan batas daerah di sekitar kapal yang akan dianalisis berupa jarak dari inlet, outlet, sides, top, bottom berdasarkan rekomendasi dari ITTC (ITTC, 2011):

Tabel 3. Ukuran Domain Boundaries

\begin{tabular}{ccc}
\hline Parameter & Background & Overset \\
\hline Panjang $(\mathrm{m})$ & 3L dari AP & 0,25L dari AP \\
& 1L dari FP & 0,25L dari FP \\
Tinggi $(\mathrm{m})$ & 2L dari keel & 0,75H dari keel \\
& 1L dari deck & 0,75H dari deck \\
Lebar (m) & 1,5 L dari symmetry & 1B dari symmetry \\
\hline Sumber: ITTC (2011)
\end{tabular}

Kondisi batas/ boundary conditions pada Tabel 4 terdiri dari; velocity inlet guna mendefinisikan kecepatan pada sisi masuk aliran incompressible, pressure outlet untuk data tekanan statik, temperatur backflow, dan besarnya turbulensi aliran balik, no-slip wall sebagai dinding pembatas antara dua fasa fluida berbeda, dan symmetry plane untuk pendefinisian model menjadi simetri tanpa adanya gesekan aliran viskos. Dari domain boundaries serta boundary conditions yang telah ditetapkan, maka gambaran dari ilustrasi virtual towing tank penelitian CFD ini dapat dilihat seperti pada Gambar 3.

Tabel 4. Sifat Boundary Conditions

\begin{tabular}{ccc}
\hline Boundary & Background & Overset \\
\hline Inlet & Velocity inlet & Overset Mesh \\
Outlet & Pressure outlet & Overset Mesh \\
Top & Velocity inlet & Overset Mesh \\
Bottom & Velocity inlet & Overset Mesh
\end{tabular}




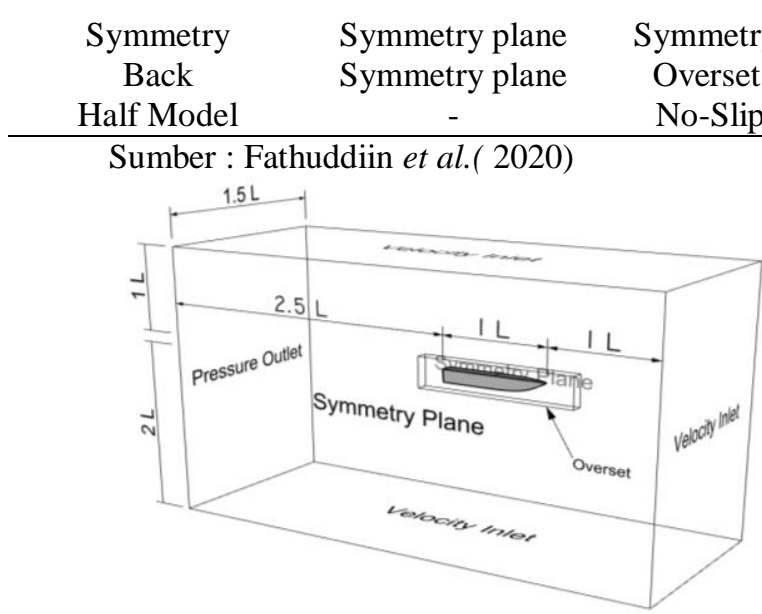

Gambar 3. Ilustrasi Virtual Towing Tank

(Sumber: Hasil Pemodelan 3D)

Overset mesh merupakan metode meshing dimana dilakukan dengan cara donor-acceptor cells (Fathuddiin et al., 2020). Ukuran kerapatan mesh dari background dan overset harus memiliki dimensi yang sama agar data dapat ditransfer secara linear (Sun et al., 2020). konsentrasi mesh berdasarkan koordinat $\mathrm{x}, \mathrm{y}$, dan $\mathrm{z}$ dengan metode anisotropic mesh. Kerapatan mesh hanya difokuskan pada permukaan badan kapal dengan visualisasi mesh pada Gambar 4 serta difokuskan pada fluida air untuk mempersingkat waktu komputasi numerik (Jokosisworo et al., 2020). Dilakukan pulah refinement pada mesh dengan menggunakan beberapa volumetric control agar merapatkan mesh secara lokal(Khazaee, Rahmansetayesh and Hajizadeh, 2019).

Tipe meshing dipilih unstructured mesh yang merupakan mesh dengan konektivitas tidak beraturan. Dengan unstructured mesh, meshing time dapat berkurang pesat dibandingkan structured mesh (ITTC, 2011).

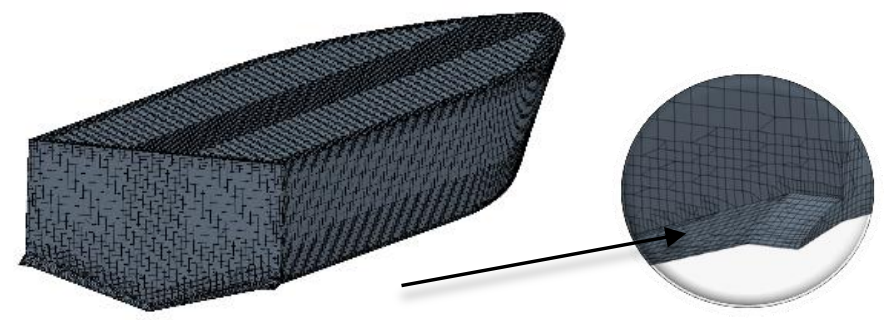

Gambar 4. Visualisasi Meshing Bagian Stern Flap (Sumber: Perangkat Lunak CFD)

Wall function $\left(\mathrm{y}^{+}\right)$merupakan dinding pemisah antara badan kapal dengan alirian fluida (Fathuddiin et al., 2020). Jumlah grid boundary layer $/ \mathrm{y}^{+}$bergantung pada model turbulensi dengan formula (Jokosisworo et al., 2020):

$\frac{y}{L}=\frac{y^{+}}{R n \sqrt{\frac{c f}{2}}}$

Dimana y merupakan tebal layer pertama, $\mathrm{R}_{\mathrm{n}}$ Reynold number, $\mathrm{L}$ ialah panjang kapal, $\mathrm{C}_{\mathrm{f}}$ merupakan koefisien gesek.

Model turbulensi digunakan untuk menggambarkan efek turbulensi aliran, dimana kali ini mengggunakan model turbulensi $k$ - $\varepsilon$ turbulence. Model ini telah menunjukan mampu memberikan prediksi yang akurat untuk hidrodinamika kapal (ITTC, 2011).

Time-step dipilih dalam perhitungan aliran unsteady bergantung pada angka CourantFriedrichs-Lewy (CFL) yang menandakan jumlah titik tempuh partikel fluida dalam interval waktu pada persamaan berikut, dengan L ialah panjang kapal dan U yaitu kecepatan kapal (Jokosisworo 
et al., 2020):

$\Delta t=0.005 \sim 0.01 \mathrm{~L} / \mathrm{U}$

\subsection{Alat Penelitian}

Alat yang digunakan untuk komputasi numerik penelitian yaitu menggunakan komputer dengan spesifikasi sebagai berikut:

OS : Windows 10 64-Bit

Processor : Intel(R) Core(TM) i7-7700HQ

RAM : $16 \mathrm{~GB}$

Grafik : NVIDIA GeForce GTX 1060

Digunakan perangkat lunak pemodelan 3D untuk memodelkan kapal serta perangkat lunak CFD berbasis komputer yang mampu menyelesaikan nilai hambatan kapal serta nilai 2-DOF kapal.

\section{Hasil Dan Pembahasan}

Dalam hasil dan pembahasan terdapat informasi berupa hasil serta pembahasan penelitian yang terdiri dari validasi hambatan kapal bare hull, hambatan viskos kapal, hambatan gelombang kapal, hambatan udara kapal, hambatan total kapal, nilai WSA kapal, nilai trim dan gaya angkat kapal, serta nilai heave kapal.

\subsection{Validasi Hambatan Kapal Bare hull}

Validasi dilakukan dengan membandingkan hasil simulasi komputasi numerik nilai hambatan kapal pada penelitian ini dengan hasil pada komputasi solver CFD lain. Diperoleh nilai hambatan terhadap Froude number seperti pada Tabel 5:

Tabel 5. Validasi Nilai Hambatan

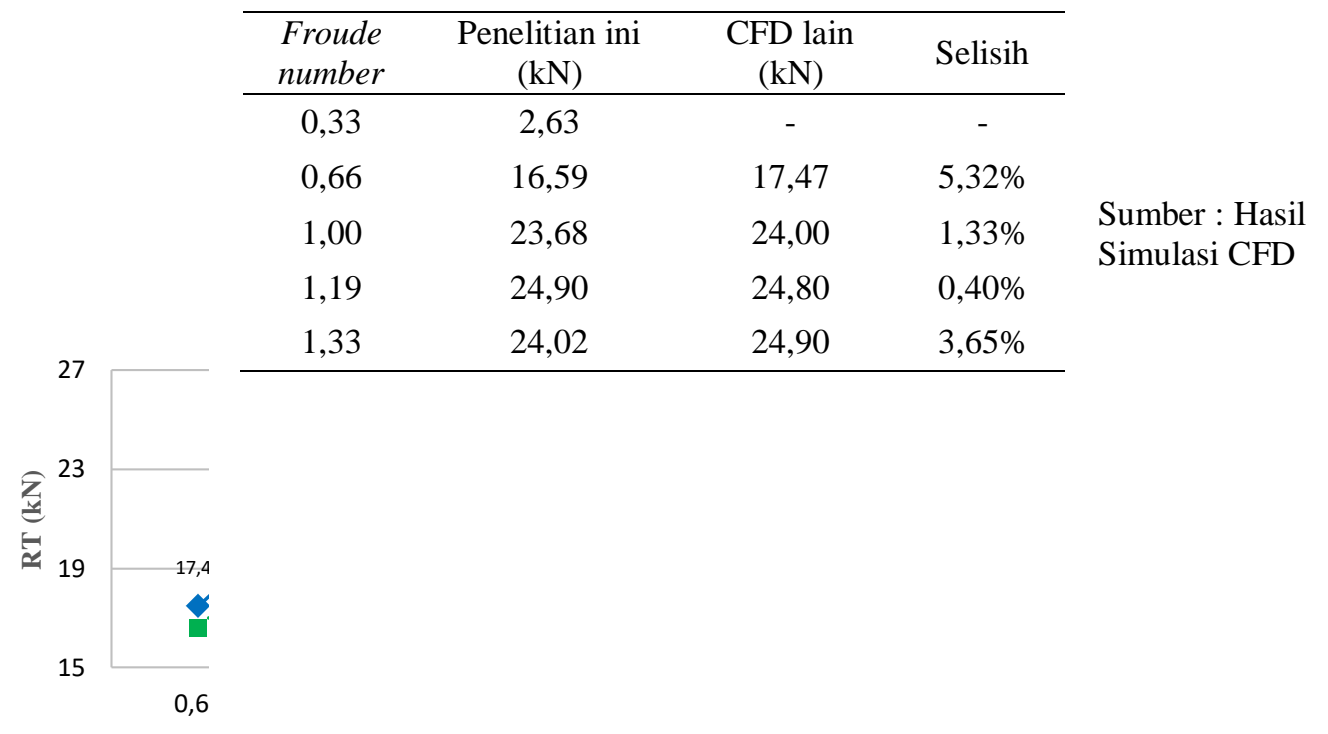

Gambar 4. Grafik validasi nilai hambatan

(Sumber: Hasil Simulasi CFD)

Dari hasil simulasi pada Gambar 4 menunjukkan bahwa nilai hambatan kedua solver CFD di atas menghasilkan error yang relatif kecil. Maka hasil simulasi numerik dianggap layak dan dapat digunakan untuk proses analisis pengaruh variasi bentuk stern flap pada penelitian. 


\subsection{Hambatan Viskos Kapal}

Berdasarkan hasil simulasi numerik pada Gambar 5 dari kapal dengan variasi stern flap, hambatan viskos berperan sebagai penyusun nilai hambatan total sebesar 13,04\% hingga 40,56\%.

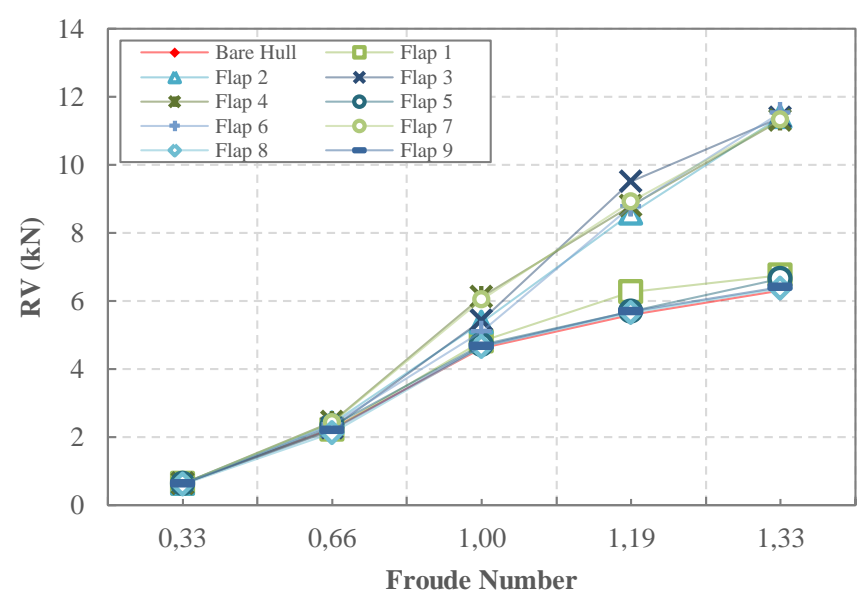

Gambar 5. Hambatan Viskos Variasi Stern flap

(Sumber: Hasil Simulasi CFD)

Jika dibandingkan dengan nilai hambatan kapal kondisi bare hull, hampir seluruh variasi stern flap mengalami peningkatan nilai hambatan viskos. Nilai hambatan viskos mengalami peningkatan yang besar pada nilai Fr 1,00, Fr 1,19, dan Fr 1,33 terutama oleh variasi Flap 2, Flap 3, Flap 4, Flap 6, dan Flap 7. Sedangkan peningkatan nilai hambatan viskos variasi Flap 1, Flap 5, Flap 8, dan Flap 9 relatif rendah.

\subsection{Hambatan Gelombang Kapal}

Hambatan gelombang merupakan hambatan yang menyebabkan hilangnya energi kapal karena pembentukan gelombang yang tercipta akibat interaksi dari fluida air dengan arah gerak badan kapal yang tercelup air (Nooryadi and Suastika, 2012).

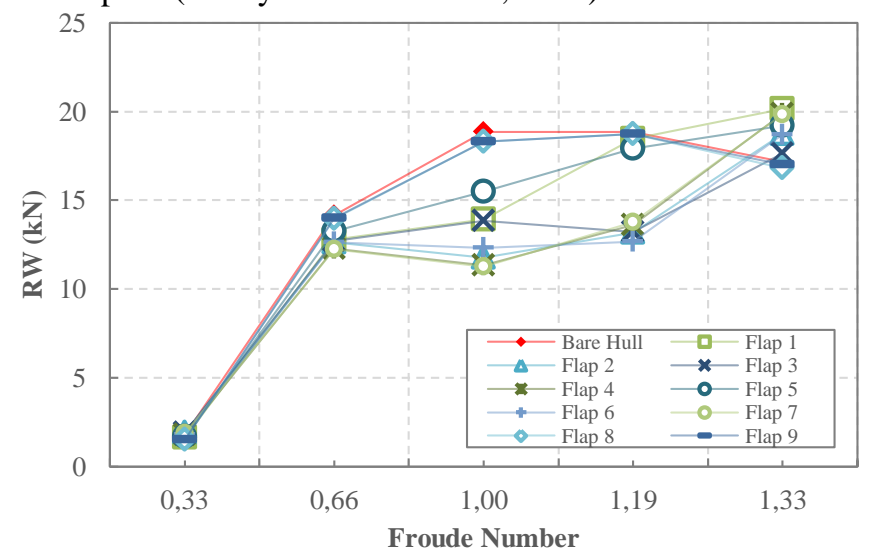

Gambar 6. Hambatan Gelombang Variasi Stern flap

(Sumber: Hasil Simulasi CFD)

Dari Gambar 6 diperoleh hambatan gelombang mendominasi sebagai komponen penyusun nilai hambatan total kapal, dengan nilai hambatan gelombang sebesar 55,67\% hingga 86,36\% dari nilai hambatan total kapal. Pada Fr 0,33 hingga Fr 1,19 nilai hambatan gelombang dari seluruh variasi stern flap mengalami penurunan jika dibandingkan dengan kapal kondisi bare hull. Didapat pula bahwa terjadi penurunan nilai hambatan gelombang yang cukup besar pada Fr 1,00 dan Fr 
1,19. Pada nilai Fr 1,33 kapal mengalami peningkatan nilai hambatan gelombang oleh Flap 1 hingga Flap 7, sementara variasi Flap 8 \& Flap 9 mengalami penurunan nilai hambatan gelombang.

\subsection{Hambatan Udara Kapal}

Hambatan udara merupakan salah satu komponen penyusun hambatan total kapal yang diakibatkan oleh pergesekan antara badan kapal di atas permukaan air dengan fluida udara. Berdasarkan Gambar 7, besar hambatan udara yang dihasilkan kapal yaitu senilai 0,03\% hingga 9,45\% dari nilai hambatan total kapal, hal ini relatif kecil jika dibandingkan nilai dengan hambatan gelombang dan hambatan viskos.

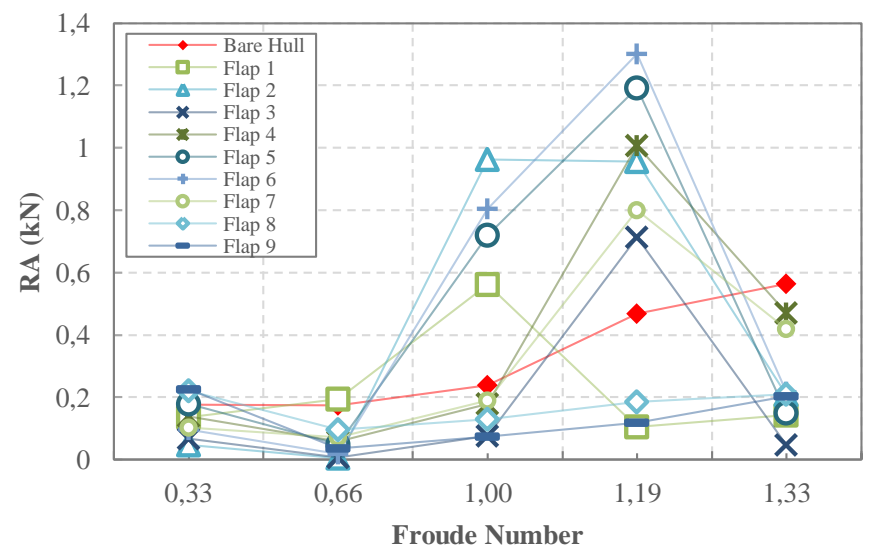

Gambar 7. Hambatan Udara Variasi Stern flap

(Sumber: Hasil Simulasi CFD)

Dari Gambar 7 didapat bahwa nilai hambatan udara dari setiap variasi stern flap cenderung fluktuatif. Akan tetapi nilai hambatan udara relatif mengalami peningkatan yang signifikan pada Fr 1,00 dan Fr 1,19, peningkatan nilai hambatan udara tersebut terjadi akibat bertambahnya luasan permukaan badan kapal yang bergesekan dengan fluida udara, kemudian mengalami pengurangan nilai hambatan udara pada Fr 1,33, yang berarti kapal semakin terbenam ke dalam fluida air.

\subsection{Hambatan Total Kapal}

Hambatan total tersusun dari 3 komponen penyusun hambatan total yaitu hambatan viskos, hambatan gelombang, dan hambatan udara. Setelah disimulasikan, diperoleh bahwa nilai hambatan total kapal didominasi oleh hambatan gelombang, lalu hambatan viskos, dan terakhir yaitu oleh hambatan udara.

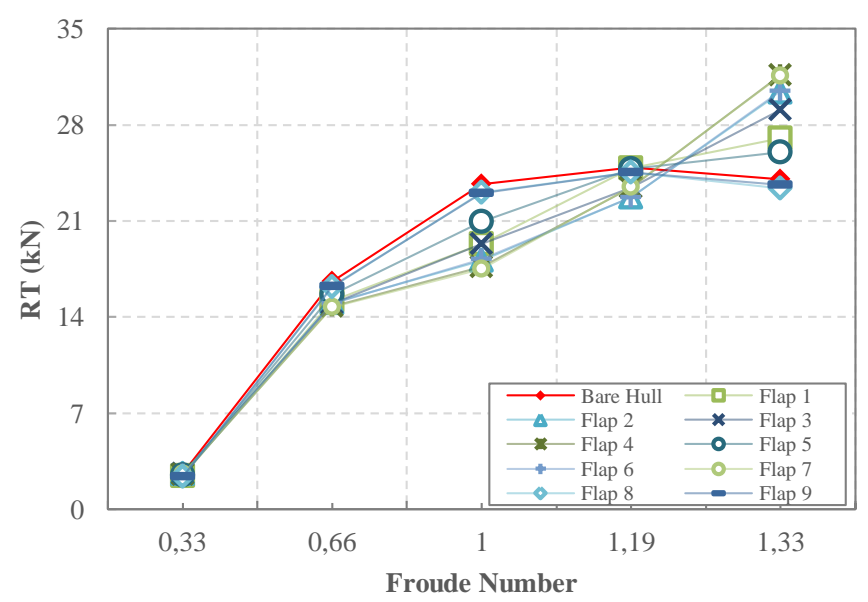

Gambar 8. Hambatan Total Variasi Stern flap 
(Sumber: Hasil Simulasi CFD)

Berdasarkan hasil simulasi numerik pada Gambar 8 didapat bahwa pada Fr 0,33 hingga Fr 1,19 stern flap variasi Flap 1 hingga Flap 9 seluruhnya memiliki kecenderungan yang sama yaitu mengalami penurunan nilai hambatan total dibandingkan kapal kondisi bare hull, bahkan didapat pengurangan nilai hambatan total tertinggi pada Fr 1,00 oleh Flap 7 sebesar -26,07\%.

Menurut Gambar 9 yang merupakan visualisasi gelombang variasi pengurangan nilai hambatan tertinggi yaitu Flap 7 pada Fr 1,00 didapat bahwa gelombang divergent pada sisi kapal berkurang serta kecuraman tinggi gelombang pada sistem gelombang menjadi lebih landai. Hal ini sesuai dengan hasil pengurangan nilai hambatan total yang didominasi oleh berkurangnya nilai hambatan gelombang yang cukup besar serta hambatan udara berkurang namun cenderung kecil.

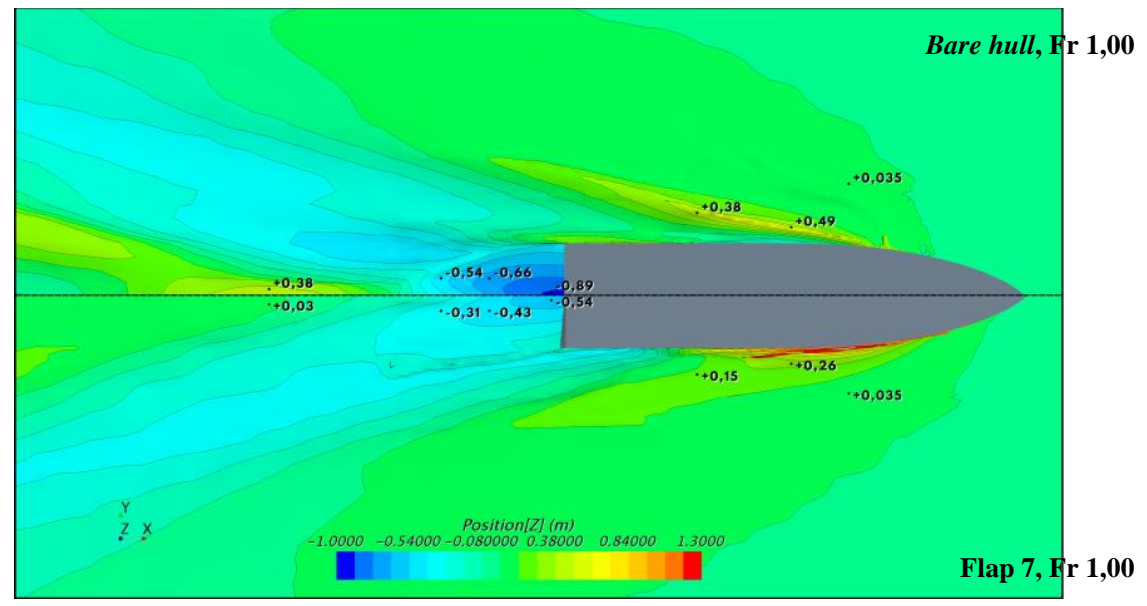

Gambar 9. Visualisasi Gelombang Flap 7, Fr 1,00

(Sumber: Hasil Simulasi CFD)

Variasi Flap 1 hingga Flap 7 pada Fr 1,33 secara drastis mengalami peningkatan nilai hambatan hingga yang tertinggi yaitu pada variasi Flap 4 sebesar 31,71\% dengan visualisasi gelombang pada Gambar 10. Bertambahnya nilai hambatan total terjadi akibat meningkatnya nilai hambatan viskos yang sangat pesat, kemudian disusul dengan bertambahnya nilai hambatan gelombang, sedangkan hambatan udara mengalami penurunan yang cenderung kecil. Hal ini menjadikan variasi Flap 1 hingga 7 hanya efektif digunakan jika kapal melaju pada Fr 0,33 hingga Fr 1,19, dan tidak efektif pada Fr 1,33.

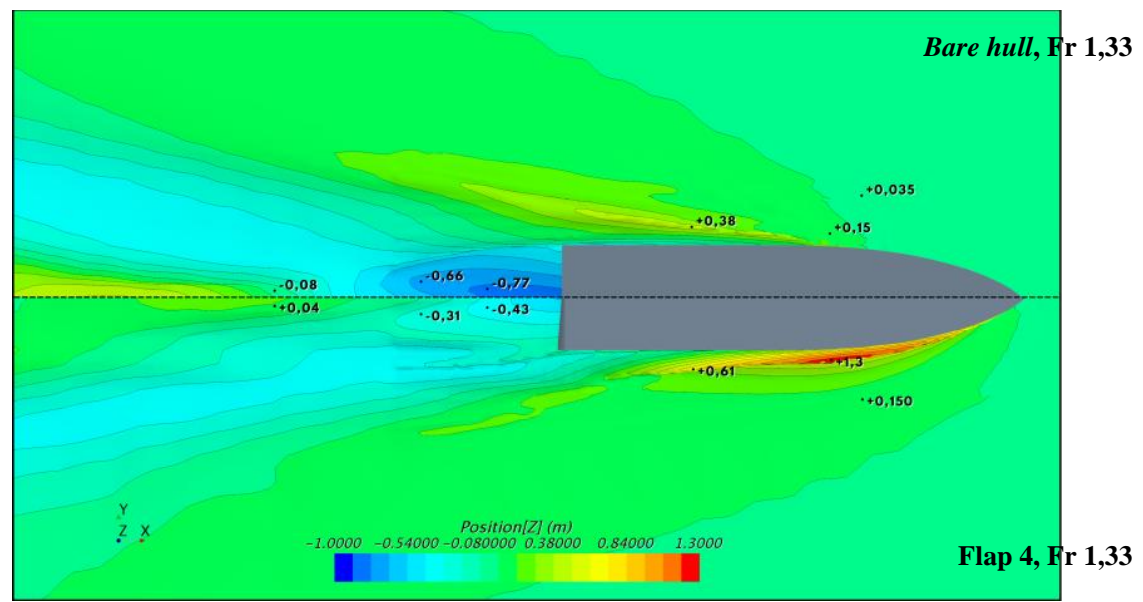

Gambar 10. Visualisasi Gelombang Flap 4, Fr 1,33

(Sumber: Hasil Simulasi CFD) 
Tidak seperti variasi Flap 1 hingga Flap 7, variasi Flap 8 dan Flap 9 secara konsisten mampu memberikan pengaruh pengurangan nilai hambatan pada seluruh Froude number dari Fr 0,33 hingga Fr 1,33. Pada Fr 1,33 variasi Flap 8 mampu mengurangi hambatan sebesar -2,67\% dan Flap 9 sebesar $-1,72 \%$. Penyebab berkurangnya nilai hambatan kedua variasi ini pada Fr 1,33 yaitu didominasi oleh berkurangnya nilai hambatan udara, kemudian disusul oleh berkurangnya nilai hambatan gelombang. Sementara hambatan viskos mengalami peningkatan yang relatif kecil.

Jika dilakukan peninjauan karakteristik geometri pada seluruh stern flap, variasi Flap 1 hingga Flap 7 memiliki kesamaan yaitu pada bagian center/ side area memiliki sudut kemiringan sebesar $10^{\circ}$, serta terdapat perbedaan panjang flap pada bagian center, side, maupun upper area. Sedangkan untuk variasi Flap 8 dan Flap 9 keduanya memiliki sudut kemiringan sebesar $0^{\circ}$ serta panjang flap yaitu $1 \% \mathrm{Lwl}$ pada bagian center, side, dan upper area.

\subsection{Nilai WSA Kapal} berikut:

Berdasarkan hasil simulasi didapatkan hasil perubahan nilai WSA seperti pada Gambar 11

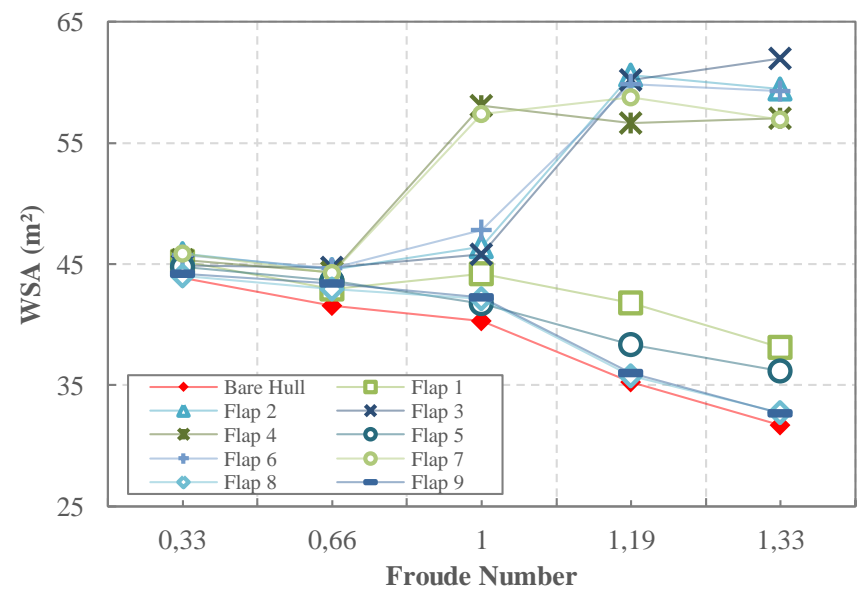

Gambar 11. Nilai WSA Variasi Stern flap

(Sumber: Hasil Simulasi CFD)

Didapat dari Gambar 11 di atas bahwa seluruh kapal dengan penambahan variasi stern flap mengalami kenaikan nilai WSA saat melaju dari Fr 0,33 hingga Fr 1,33 jika dibandingkan dengan nilai WSA yang dimiliki kapal bare hull.

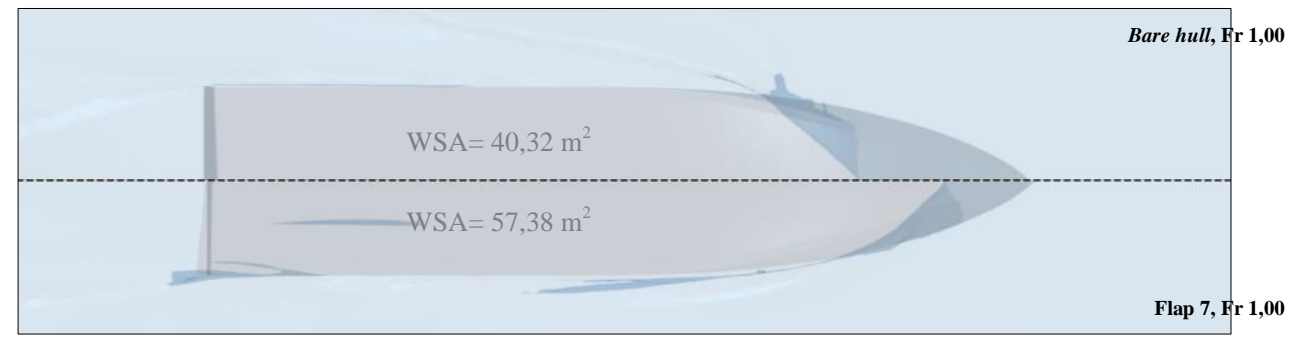

Gambar 12. WSA Variasi Flap 7, Fr 1,00

(Sumber: Hasil Simulasi CFD)

Meningkatnya nilai WSA kapal setelah instalasi stern flap berbanding lurus dengan peningkatan nilai hambatan viskos kapal. Akibatnya didapat peningkatan nilai WSA yang cukup tinggi pada Fr 1,00, Fr, 1,19, dan Fr 1,33 oleh variasi Flap 2, Flap 3, Flap 4, Flap 6, dan Flap 7 menyebabkan nilai hambatan viskos bertambah secara drastis. Sementara peningkatan nilai WSA yang cenderung rendah pada variasi Flap 1, Flap 5, Flap 8, dan Flap 9 juga menghasilkan nilai 
hambatan viskos yang rendah.

Nilai WSA yang diperoleh variasi pengurangan nilai hambatan tertinggi yaitu Flap 7 pada Fr 1,00 dengan variasi penambah nilai hambatan tertinggi Flap 4 pada Fr 1,33 keduanya mengalami kenaikan nilai WSA yang cukup tinggi, sehingga hambatan viskos kapal pada kedua variasi ini mengalami peningkatan. Namun jika membandingkan visualisasi WSA pada Gambar 12 dan Gambar 13 diperoleh bahwa fraksi volum dari fluida air didapat lebih besar pada variasi Flap $4 \mathrm{Fr}$ 1,33, hal ini menyababkan bertambahnya nilai hambatan viskos pada variasi Flap 4 Fr 1,33 jauh lebih besar dibandingkan oleh Flap 7 Fr 1,00.

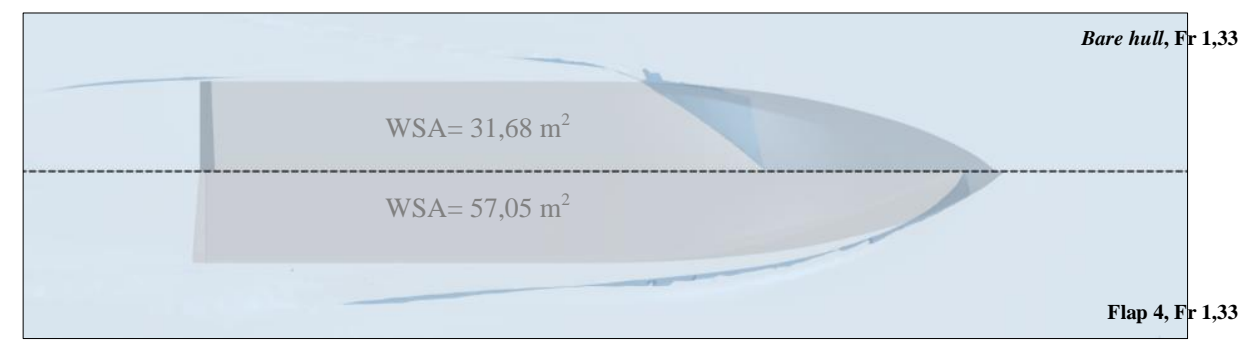

Gambar 13. WSA Variasi Flap 4, Fr 1,33

(Sumber: Hasil Simulasi CFD)

\subsection{Nilai Trim dan Gaya Angkat Kapal}

Perolehan perubahan nilai trim kapal dipengaruhi sebab adanya perubahan nilai lift force yang dihasilkan dari instalasi stern flap. Maka dari itu didapat nilai trim ialah seperti pada Gambar 14.

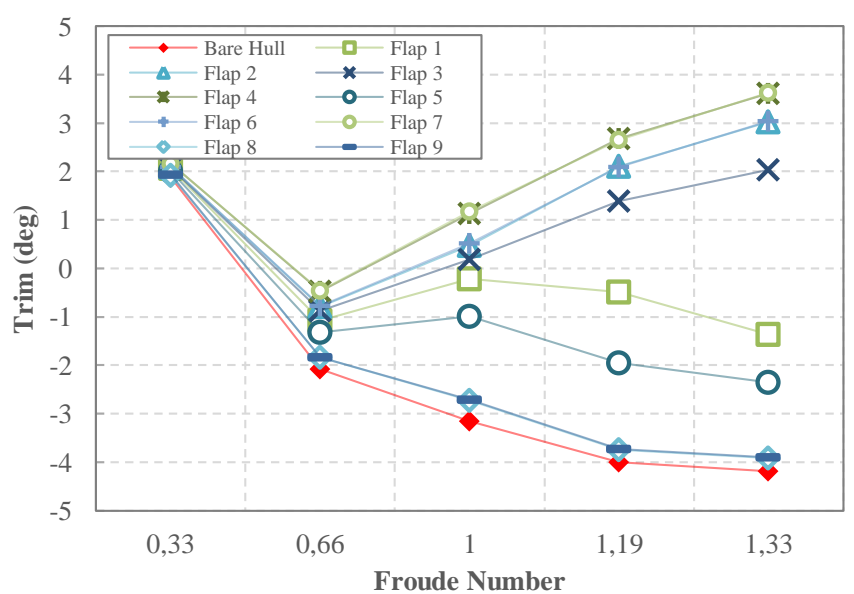

Gambar 14. Nilai Trim Variasi Stern flap

(Sumber: Hasil Simulasi CFD)

Dari hasil simulasi pada Gambar 14 diperoleh bahwa kapal bare hull selama melaju dari kecepatan rendah hingga maksimum mengalami tren trim kapal terhadap buritan yang terus meningkat hingga nilai trim buritan terbesar pada Fr 1,33 sebesar $4,19^{\circ}$. 


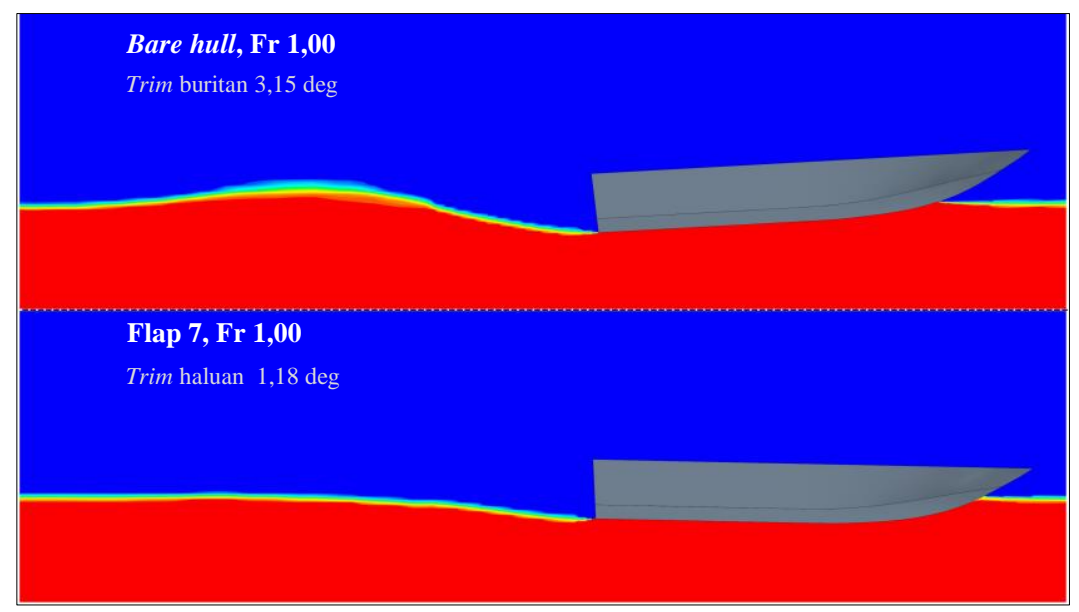

Gambar 15. Trim Variasi Flap 7, Fr 1,00

(Sumber: Hasil Simulasi CFD)

Setelah disimulasikan penambahan variasi stern flap, didapat pada Fr 0,33 dan Fr 0,66 kecenderungan hasil simulasi semua variasi memiliki nilai yang tidak jaub berbeda, namun semakin tinggi kecepatan kapal, nilai trim semakin bervariasi. Perubahan nilai trim pada kapal cepat planing hull mampu memberikan dampak besar pada perubahan nilai hambatan viskos, hambatan gelombang, dan hambatan udara kapal sebab sifat nilai trim kapal planing hull yang cenderung berubah-ubah sepanjang bertambahnya nilai Froude number kapal.

Dari variasi stern flap dengan pengurangan nilai hambatan tertinggi yaitu Flap 7 pada Fr 1,00 diperoleh visualisasi trim kapal pada Gambar 15 yang mengalami kenaikan menjadi trim haluan namun sudut trim relatif kecil atau mendekati kondisi even keel. Komponen hambatan yang berperan tinggi pada pengurangan nilai hambatan yaitu ialah hambatan gelombang, disusul oleh hambatan udara, sedangkan hambatan viskos mengalami peningkatan.

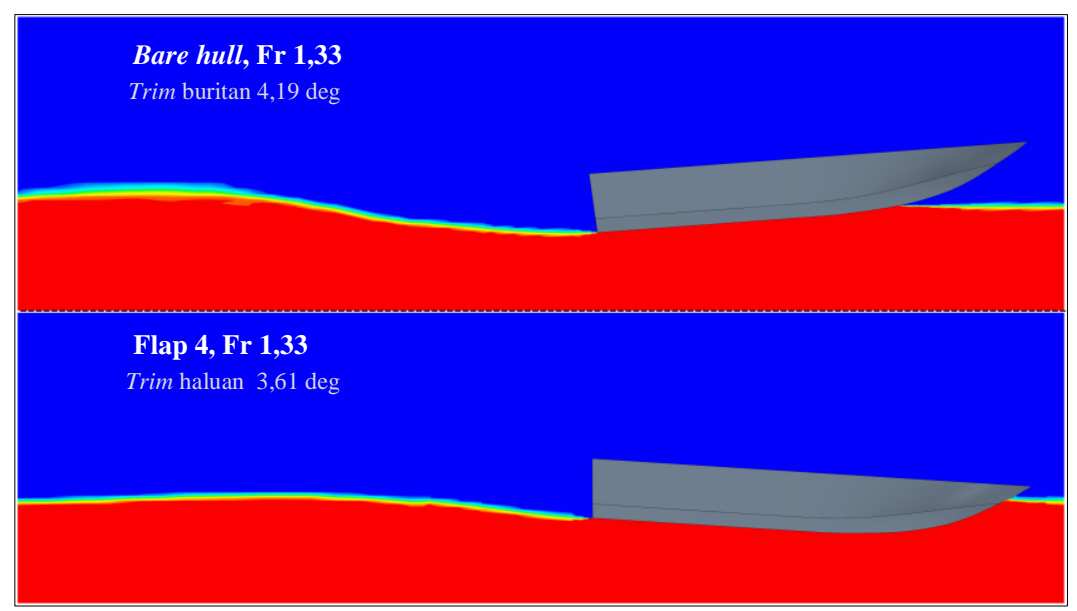

Gambar 16. Trim Variasi Flap 4, Fr 1,33

(Sumber: Hasil Simulasi CFD)

Disamping itu, nilai sudut trim haluan yang terlalu besar seperti yang terjadi pada visualisasi trim dari Gambar 16 dapat memberikan dampak buruk yaitu mampu menambah nilai hambatan viskos dan gelombang pada kapal planing hull secara signifikan saat kapal melaju pada kecepatan tinggi, trim haluan ini menyebabkan badan kapal semakin terbenam pada fluida air hingga nilai WSA bertambah, hal ini terjadi pada stern flap variasi Flap 2, Flap 3, Flap 4, Flap 6, dan Flap 7 pada Fr 1,33 .

Sebaliknya, nilai trim buritan yang ideal didapat mampu memberi mengurangan nilai 
hambatan kapal planing hull pada kecepatan tinggi, berkurangnya nilai hambatan ini didominasi oleh berkurangnya nilai hambatan udara dan hambatan gelombang sedangkan hambatan viskos tetap mengalami kenaikan akibat WSA yang meningkat namun nilainya relatif kecil, sebagai contoh ialah variasi Flap 8 dan Flap 9 pada Fr 1,33.

Perubahan nilai trim kapal dipengaruhi oleh perbedaan gaya angkat yang terjadi pada bagian stern flap serta gaya angkat pada bagian badan kapal sepanjang bertambahnya nilai Froude number.

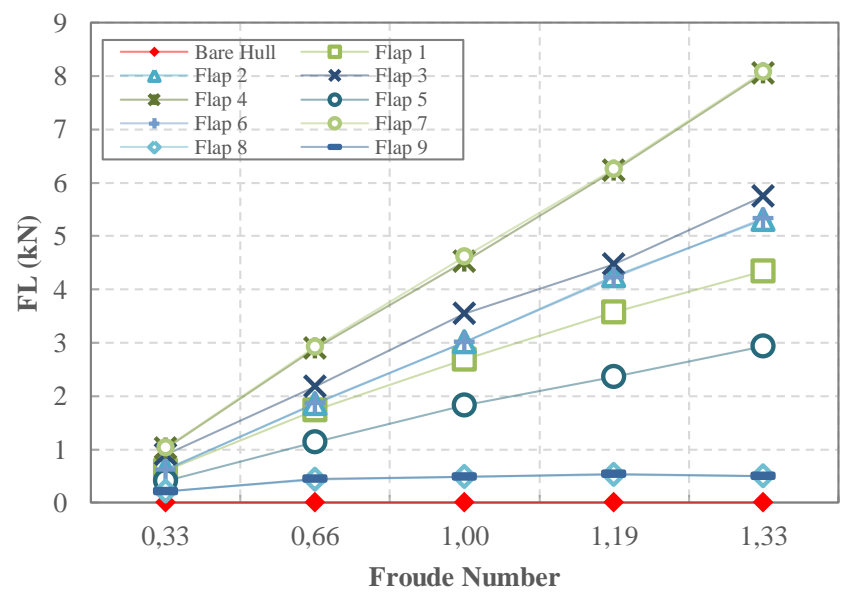

Gambar 17. Gaya Angkat pada Stern flap

(Sumber: Hasil Simulasi CFD)

Dari Gambar 17 diperoleh bahwa seiring bertambahnya nilai Froude number, besarnya nilai lift force yang terjadi pada stern flap secara konsisten mengalami peningkatan. Variasi stern flap dengan nilai gaya angkat tertinggi diperoleh oleh variasi Flap 7, sementara nilai lift force terendah didapat oleh variasi Flap 8.

Semakin besar gaya angkat pada stern flap, maka bagian buritan kapal semakin terangkat ke atas, hal ini mempengaruhi perubahan nilai trim kapal juga berdampak pada perubahan nilai WSA kapal hingga akhirnya mempengaruhi nilai hambatan total kapal.

Jika ditinjau dari bentuk geometri stern flap, variasi yang memiliki sudut kemiringan $10^{\circ}$ mengalami peningkatan gaya angkat yang besar pada stern flap seiring bertambahnya nilai Froude number kapal, variasi ini ialah Flap 1 hingga Flap 7.

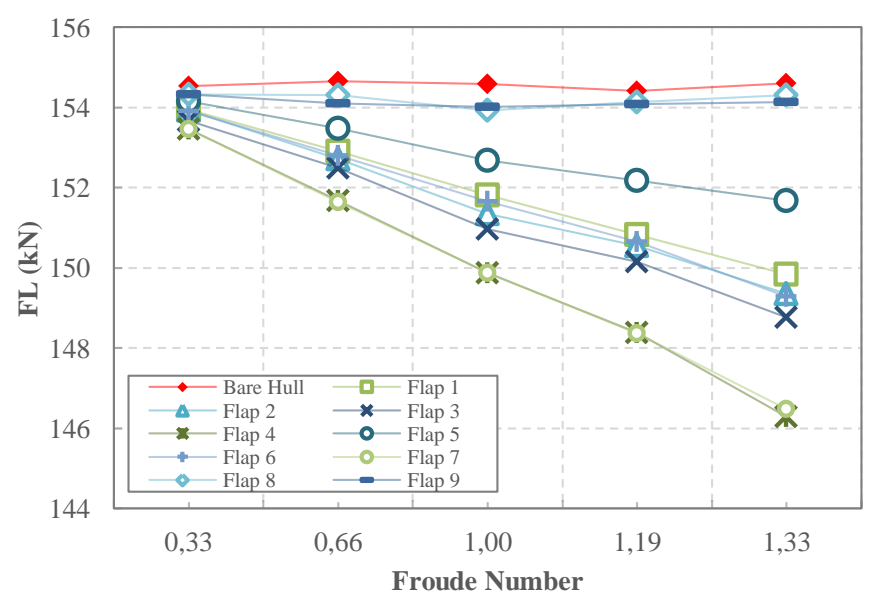

Gambar 18. Gaya Angkat pada Badan Kapal

(Sumber: Hasil Simulasi CFD)

Berkebalikan dengan gaya angkat yang terjadi pada stern flap, dari Gambar 18 didapat gaya 
angkat pada bagian badan kapal justru mengalami tren penurunan nilai gaya angkat seiring bertambahnya nilai Fr kapal, dampak dari hal ini ialah badan kapal semakin terbenam terutama pada bagian haluan kapal, mengakibatkan kapal trim haluan sebab pada bagian buritan kapal nilai gaya angkat bertambah.

\subsection{Nilai Heave Kapal}

Berdasarkan grafik hasil simulasi nilai heave pada Gambar 19 diperoleh bahwa untuk kapal kondisi bare hull seiring bertambahnya kecepatan, nilai heave kapal semakin tinggi.

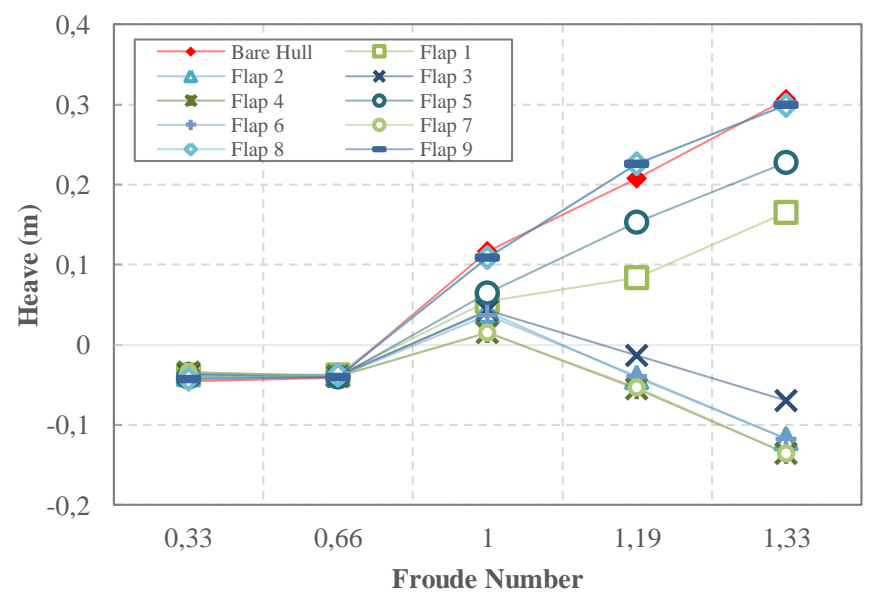

Gambar 19. Nilai Heave Variasi Stern Flap

(Sumber: Hasil Simulasi CFD)

Setelah dilakukan simulasi penambahan variasi stern flap, didapat bahwa pada Fr 0,33 dan Fr 0,66 seluruh variasi memiliki nilai heave yang cenderung tidak terlalu berbeda, seiring bertambahnya kecepatan kapal, nilai heave tiap variasi semakin beragam namun tidak berubah secara signifikan.

Saat kapal melaju pada kecepatan maksimum atau Fr 1,33, didapat kenaikan nilai heave tertinggi pada variasi Flap 8 dan Flap 9, dimana hanya kedua variasi inilah yang mampu mengurangi nilai hambatan pada kecepatan maksimum.

\section{Kesimpulan}

Dari hasil simulasi numerik di atas yang bertujuan untuk menganalisis pengaruh variasi stern flap terhadap nilai hambatan total kapal patroli $14 \mathrm{~m}$ dengan berbentuk planing hull diperoleh bahwa terjadi pengurangan nilai hambatan tertinggi oleh variasi Flap 7 pada Fr 1,00 sebesar 26,07\% akibat berkurangnya nilai hambatan gelombang yang cukup besar, kemudian penambahan nilai hambatan tertinggi oleh variasi Flap 4 pada Fr 1,33 sebesar 31,71\% akibat bertambahnya hambatan viskos yang besar serta bertambahnya hambatan gelombang. Namun variasi Flap 1 hingga Flap 7 hanya mampu mengurangi nilai hambatan pada Fr 0,33 hingga Fr 1,19, sedangkan pada Fr 1,33 variasi stern flap tersebut sudah tidak efektif lagi sebab terjadi peningkatan nilai hambatan viskos yang sangat signifikan.

Variasi Flap 1 hingga Flap 7 memiliki kemiripan karakteristik geometri sehingga didapat bahwa stern flap dengan perbedaan sudut dan perbedaan panjang flap antara bagian center, side, dan upper area menyebabkan stern flap menjadi kurang efektif pada kecepatan tinggi.

Adapun Variasi yang mampu memberi pengurangan nilai hambatan pada seluruh Froude number ialah variasi Flap 8 dan Flap 9, dimana kedua variasi ini memiliki karakteristik geometri nilai sudut flap sebesar $0^{\circ}$ dan panjang flap $1 \%$ Lwl. Pada kedua variasi ini pengurangan nilai hambatan total didominasi oleh berkurangnya nilai hambatan udara, kemudian disusul oleh berkurangnya nilai hambatan gelombang, sementara hambatan viskos mengalami peningkatan yang relatif kecil.

Gaya angkat yang dihasilkan stern flap semakin besar seiring bertambahnya nilai Froude number kapal, sementara gaya angkat pada bagian badan kapal semakin berkurang, hal ini 
menyebabkan buritan kapal semakin terangkat dan kapal yang mulanya trim buritan berubah menjadi trim haluan.

Perubahan trim berperan besar terhadap perubahan nilai hambatan total kapal. Dimana variasi dengan sudut flap $10^{\circ}$ mampu menyebabkan kapal trim haluan terutama pada Fr 1,33, akibatnya WSA kapal meningkat dan hambatan viskos kapal bertambah besar. Sedangkan variasi stern flap dengan sudut flap $0^{\circ}$ pada Fr 1,33 mampu menghasilkan trim yang baik terhadap nilai hambatan hingga penambahan hambatan viskos cenderung kecil.

Untuk peninjauan nilai heave, diperoleh bahwa kapal akibat instalasi stern flap mengalami perubahan nilai heave yang relatif kecil, sehingga peran heave pada perubahan nilai hambatan tidak terlalu berarti.

\section{Ucapan Terima Kasih}

Penulis mengucapkan terima kasih kepada Laboratorium Perancangan Kapal Dibantu Komputer Universitas Diponegoro atas fasilitas dan dukungannya dalam melakukan penelitian ini.

\section{Daftar Pustaka}

Bertram, V. (2012) Practical Ship Hydrodynamics. 2nd Edition. Oxford: Elsevier's Science \& Technology.

Fathuddiin, A., Samuel, and Kiryanto (2020), Prediksi Hambatan Kapal dengan Menggunakan Metode Overset Mesh pada Kapal Planing Hull, Jurnal Rekayasa Hijau, 4(1), pp. 24-34. doi: 10.26760/jrh.v4i1.24-34.

Fretes, E. R. D. (2018), Analisa Numerik Pemilihan Geometri Fin Buritan untuk Kapal-Kapal Speed Boat yang Beroperasi di Ambon dan Sekitarnya, in Archipelago Engineering, pp. 8085 .

ITTC (2011), Practical Guidelines for Ship CFD Applications, in ITTC - Recommended Procedures and Guidelines ITTC, pp. 1-18.

Jokosisworo, S., Iqbal, M., Manik, P., and Rindo, G. (2020), Verifikasi Deep - V Planing Hull Menggunakan Finite Volume Method Pada Kondisi Air Tenang', TEKNIK, 41(2), pp. 126133. doi: 10.14710/teknik.v41n2.29391.

Khazaee, R., Rahmansetayesh, M. A. and Hajizadeh, S. (2019), Hydrodynamic Evaluation of A Planing Hull in Calm Water Using RANS and Savitsky's Method', Ocean Engineering. Elsevier Ltd, 187, p. 106221. doi: 10.1016/j.oceaneng.2019.106221.

Klara, S., Mahmuddin, F., Hariyanto, S., Sitepu, G., and Aman, A. A. (2020), Effect of Different Stern Flap Position and Size as an Energy Saving Device (ESD) for Increasing Fishing Boat Speed, IOP Conference Series: Materials Science and Engineering, 875(1). doi: 10.1088/1757-899X/875/1/012079.

Maki, A., Arai, J., Tsutsumoto, T., Suzuki, K., and Miyauchi, Y. (2016), Fundamental Research on Resistance Reduction of Surface Combatants due to Stern Flaps, Journal of Marine Science and Technology (Japan), 21(2), pp. 344-358. doi: 10.1007/s00773-015-0356-8.

Maulana, A. (2018), Analisa Penambahan Stern Flap pada Kapal Hull Planing Chine Axe Bow Pengaruhnya Terhadap Tahanan Kapal. Institut Teknologi Sepuluh Nopember. Available at: http://repository.its.ac.id/id/eprint/50140.

Muhamad, S. V. (2012), Illegal Fishing di Perairan Indonesia: Permasalahan dan Upaya 
Penanganannya Secara Bilateral di Kawasan', Jurnal Ilegal Fishing, 3(1), pp. 59-86. doi: 10.1002/asi.

Nooryadi, L. and Suastika, K. (2012), Perhitungan Wave Making Resistance pada Kapal Katamaran dengan Menggunakan CFD', Jurnal Teknik ITS, 1(1), pp. 30-34.

Song, K. W., Guo, C. Y., Gong, J., Li, P., and Wang, L. Z. (2018), Influence of interceptors, stern flaps, and their combinations on the hydrodynamic performance of a deep-vee ship, Ocean Engineering, 170, pp. 306-320. doi: 10.1016/j.oceaneng.2018.10.048.

Song, K. W., Guo, C. Y., Wang, C., Sun, C., Li, P., and Wang, W. (2019) , Numerical analysis of the effects of stern flaps on ship resistance and propulsion performance, Ocean Engineering. Elsevier Ltd, 193, p. 106621. doi: 10.1016/j.oceaneng.2019.106621.

Sun, C., Xu, X., Wang, W., and Xu, H. (2020), Influence on Stern Flaps in Resistance Performance of a Caterpillar Track Amphibious Vehicle, IEEE Access, 8, pp. 123828123840. doi: 10.1109/ACCESS.2020.2993372.

Widyatmoko, A., Samuel, S., Manik, P., and Trimulyono, A. (2021), Analisis Pengaruh Jumlah Bilge Keel terhadap Gerakan Rolling pada Kapal Patroli 14 m', Warta Penelitian Perhubungan, 33(1), pp. 1-10. doi: 10.25104/warlit.v33i1.1667.

Yaakob, O., Shamsuddin, S. and Koh, K. K. (2012), Stern Flap for Resistance Reduction of Planing Hull Craft: A Case Study with a Fast Crew Boat Model, Jurnal Teknologi, 41(1). doi: $10.11113 /$ jt.v41.689. 
